\title{
New combinations and a new species of Eriogonum (Polygonaceae: Eriogonoideae) from the Great Basin Desert, United States
}

\author{
BEN R. GRADY ${ }^{1} \&$ JAMES L. REVEAL ${ }^{2}$ \\ ${ }^{1}$ Department of Botany, University of Wisconsin, 430 Lincoln Drive, Madison, Wisconsin 53706, U.S.A.; e-mail: brgrady@wisc.edu \\ ${ }^{2}$ L.H. Bailey Hortorium Herbarium, Department of Plant Biology, Cornell University, 412 Mann Library, Ithaca, New York 14853, \\ U.S.A.; e-mail: jlr326@cornell.edu
}

\begin{abstract}
Three new species of Eriogonum have been identified from field research and ongoing molecular systematic analysis of selected members of Eriogonum subg. Eucycla. Eriogonum alexanderae, formerly recognized as a variety of E. ochrocephalum or subsumed within E. crosbyae, warrants species-level designation. Eriogonum calcareum, also previously recognized as a variety of E. ochrocephalum, shares many affinities with the narrowly distributed $E$. novonudum, however range and morphology do not overlap between these two species. Eriogonum crosbyae var. mystrium shares a more similar evolutionary history to E. crosbyae, rather than E. prociduum, thus a new combination is proposed. Eriogonum domitum is described as a new species. This isolated taxon from west-central Utah is no longer thought to be a member of E. mancum, differing in morphological characters, geographic distribution and molecular information.
\end{abstract}

Key words: Edaphic endemism, subgenus Eucycla, wild buckwheat

\section{Introduction}

While much of the vegetation throughout the Great Basin Desert is relatively homogenous, the rich geological history and heterogenous edaphic substrates create islands of potential evolutionary endemism. Eriogonum Michaux (1803: 246) is a prime example of a plant genus that matches this landscape diversity with species diversity. Consisting of over 250 species, Eriogonum is one of the most species rich genera found in North America (Reveal 2005). As more and more field and molecular research is conducted, additional revised and previously undescribed species of Eriogonum come to light. Here we propose three species, Eriogonum alexanderae and Eriogonum calcareum, formerly recognized as varieties of E. ochrocephalum Watson (1880: 480), and Eriogonum domitum previously confused with E. mancum Rydberg (1917: 220). In addition, a novel combination is proposed. Eriogonum crosbyae var. mystrium is more closely related to E. crosbyae Reveal (1981) than it is to E. prociduum Reveal (1972: 442), based on DNA sequence data. Because these taxa are perennial and possess flowers that lack a simple, stipe-like extension of the perianth, they are classified in Eriogonum subg. Eucycla (Nuttall 1848: 16) Kuntze (1903: 204).

\section{Taxonomic Treatment}

Eriogonum alexanderae (Reveal) Grady \& Reveal, comb. \& stat. nov., based on E. ochrocephalum S. Watson var. alexanderae Reveal (1985: 276). TYPE:-U.S.A. Nevada: Lyon County: Wilson Canyon, $12.8 \mathrm{mi}$ NE of Smith, Lyon Co., Nevada, 21 June 1978, Reveal et al. 4737 (holotype US, isotypes ASU, 
Eriogonum alexanderae, a robust caespitose perennial, is sufficiently different from other capitate members of Eriogonum subg. Eucycla to be recognized as a distinct species. Initially, this taxon was included in $E$. ochrocephalum as a variety (Reveal 1985). The treatment of the genus for the Flora of North America included E. alexanderae in the broadly circumscribed E. crosbyae as these taxa share similar growth forms, tomentose flowering stems, and similar floral morphologies (Reveal 2005). Eriogonum alexanderae differs from both E. crosbyae and E. ochrocephalum in a number of respects, including morphology, distribution, and genetic identity.

Eriogonum alexanderae occurrences are limited to three western Nevada counties (Douglas, Lyon, and Mineral) in the southwestern Great Basin Desert. Here it can be found in discrete populations at elevations of $1400 \mathrm{~m}$ to $2100 \mathrm{~m}$ on clay hills and slopes. The Alexander wild buckwheat flowers from May to July. As such, the species occurs to the southeast of the current distribution of E. ochrocephalum. While these two entities can be found in the same general geographic region, their ranges do not overlap. The tomentose flowering stem of E. alexanderae is the most distinguishing feature when comparing it to E. ochrocephalum as the latter has glabrous to slightly glandular flowering stems that are never tomentose. The involucre shape also differs with those of E. alexanderae being turbinate, while those of E. ochrocephalum are generally campanulate.

Prior to this taxonomic treatment, Eriogonum alexanderae was considered to be a variety of the more widespread species, E. crosbyae (Reveal 2005). DNA sequence data, both chloroplast and nuclear, indicate that E. alexanderae is not as closely related to E. crosbyae as previously thought (Grady \& Sytsma, unpublished data). Clear morphological distinctions can also be made between the two species. Eriogonum crosbyae, as now defined, is a more diminutive plant, with a compact, mat-forming habit. Eriogonum alexanderae is a larger, more robust caespitose species. Along these same lines, leaf size varies noticeably with the leaf blades of E. alexanderae 5-15 mm wide, whereas the blades of mature leaves of E. crosbyae are narrower than $5 \mathrm{~mm}$ (Reveal 1981, 1985). The involucre length is another feature that distinguishes $E$. alexanderae $(>4 \mathrm{~mm})$ from E. crosbyae $(<3.5 \mathrm{~mm})$.

Additional specimens examined:-U.S.A. Nevada: Douglas Co.: Pine Nut Mountains, Hoye Canyon at extreme SE end of the range, $1.6 \mathrm{rd} \mathrm{mi} \mathrm{S} \mathrm{of} \mathrm{Jack} \mathrm{Wright} \mathrm{Summit} \mathrm{on} \mathrm{Nevada} \mathrm{Highway} \mathrm{208,} \mathrm{on} \mathrm{a} \mathrm{dirt} \mathrm{road} \mathrm{to}$ Walker River, growing with pinyon-juniper on light-colored clay hills, T10N, R23E, Sec. 9, $5250 \mathrm{ft}$ elev., 9 June 1998, Tiehm 12380 (NY, UTC). Lyon Co.: W of Wilson Canyon on the S side of Nevada Hwy 208, 5.9 rd $\mathrm{mi}$ E of Smith, associated with Atriplex, Ephedra, and Camissonia, 38 48 $25.7^{\prime \prime} \mathrm{N}, 119^{\circ} 13^{\prime} 18.5^{\prime \prime} \mathrm{W}, 1427 \mathrm{~m}$ elev., 26 June 2008, Grady 413 (NY, WIS); along Nevada Highway 338, 0.6 mile NW of U.S. Forest Service Road 028 (toward Conway Stage Station), 8.2 miles N of the California state line, on clay slopes associated with Artemisia, 38 $26^{\prime} 58^{\prime \prime} \mathrm{N}, 119^{\circ} 08^{\prime} 12^{\prime \prime} \mathrm{W}$, T7N, R25E, Sec. 24, ca. $6000 \mathrm{ft}$ elev., 18 August 1992, Reveal 7292 (MARY); same location, 5 June 2007, Reveal 8845 (MARY); Aldrich Grade along Nevada Hwy 3C, N of Fletcher Springs, growing with pinyon-juniper on white clay hills, T7N, R27E, Sec. 12, $6300 \mathrm{ft}$ elev., 6 June 1981, Tiehm 6558 (CAS, MO, NY, UTC); 0.5 rd mi NW on Nevada Highway 22 [now 338] from the rd E along the East Walker River, growing with pinyon pine and Artemisia on whitish clay hillsides, T7N, R25E, Sec. 24, 6000 ft elev., 6 June 1981 Tiehm 6527 (CAS, MO, NY, UTC); NE of Pine Nut Mtns, Bull Canyon, 2.7 rd mi SSW of the main pole line rd, growing on brown clayey slopes, T16N R23E, Sec. 28, $5200 \mathrm{ft}$ elev., 21 May 1999, Tiehm 12805 (NY, UTC). Mineral Co.: Bodie Hills, $1.3 \mathrm{rd}$ mi from Bodie Road on the rd to Aurora, growing with pinyon-juniper on white-colored ash deposits, T5N, R28E, Sec. 6, $6700 \mathrm{ft}$ elev., 12 July 1983, Tiehm \& Lavin 8111 (CAS, NY, UTC); Garfield Hills, 9.1 rd mi S of Lucky Boy Pass Road on Nevada Highway 359 to Mono Lake, then $4.6 \mathrm{rd}$ mi on a dirt rd, growing on light-colored clay outcrops, T6N, R31E, Sec. 23, 6000 ft elev., 20 June 1998, Tiehm \& Nachlinger 12517 (NY, UTC). 
Eriogonum calcareum (S.Stokes) Grady \& Reveal, comb. \& stat. nov., based on E. ochrocephalum S. Watson subsp. calcareum Stokes (1936: 92). TYPE:-U.S.A. Oregon: Malheur County: near Harper Ranch, 13 June 1896, Leiberg 2254 (lectotype GH, designated by Reveal (2004a: 188), duplicates F, K, NY, ORE, P, POM, S, US).

Eriogonum ochrocephalum S.Watson var. sceptrum Reveal (1989: 252). TYPE:-U.S.A. Idaho: Owyhee County: $11 \mathrm{mi}$ SW of Bruneau, 7 July 1974, Reveal 3687 (holotype US, isotypes ARIZ, ASU, BRY, COLO, DAV, GH, IDS, GH, NY, RM, RSA, TEX, UTC).

Eriogonum calcareum occurs on fine-grained substrates scattered across the north-central Great Basin at elevations of 700 to $1000 \mathrm{~m}$ in Elmore, Owyhee, Payette, and Twin Falls counties of Idaho, and in Baker and Malheur counties in Oregon. The Harper wild buckwheat flowers from May to June. Recent molecular work (Grady \& Sytsma, unpublished data) has shed new light on the closest relatives of E. calcareum, confirming that E. calcareum is most closely related to the Oregon endemic, E. novonudum Peck (1945: 178). While it is clear now that these two species are closely related, they do not grow sympatrically. Additionally, the inflorescence-type is sufficient to differentiate these two species, with E. calcareum having its involucres in a capitate or subcapitate cluster atop its flowering stem, while the involucres of $E$. novonudum are arranged in a cymose inflorescence.

Eriogonum calcareum, and the related E. novonudum, are not closely allied to E. ochrocephalum, thus it is no longer included as a variety. The Harper wild buckwheat occurs well to the north of other populations of $E$. ochrocephalum; the closest known populations being separated by a distance of at least $400 \mathrm{~km}$. The turbinate involucres of E. calcareum distinguish it from E. ochrocephalum which has campanulate involucres.

Additional specimens examined:-U.S.A. Idaho: Elmore Co.: $1 \mathrm{mi} \mathrm{W}$ of King Hill, T5S R10E, Sec. 12, 2600 ft elev., 12 June 1989, DeBolt 1146 (NY); Glenn's Ferry Formation above Rosevear Gulch S of Glenn's Ferry, on heavy clay hillsides, $43^{\circ} 01^{\prime} \mathrm{N}, 115^{\circ} 15^{\prime} \mathrm{W}, 3000 \mathrm{ft}$ elev., 13 May 1980, Grimes et al. 1544 (CAS, NY); along U.S. Highway 30 near Glenn's Ferry, $5 \mathrm{mi} \mathrm{W}$ of King Hill at milepost 151.5 on a steep clay road bank above the Snake River, T5S, R10E, Sec. 21, $2600 \mathrm{ft}$ elev., 13 July 1975, Reveal 3898 (BRY, CAS, DUKE, F, GH, MICH, MO, NY, OKL, RSA, TEX, UTC); SE of Payette, $2100 \mathrm{ft}$ elev., 3 June 1945, Ripley \& Barneby 6546 (NY). Owyhee Co.: Ca $1.5 \mathrm{mi} \mathrm{N}$ of Little Jacks Creek via Vaught Road, white sandy-clay lacustrine soils, $42^{\circ} 49^{\prime} \mathrm{N}, 116^{\circ} 00^{\prime} \mathrm{W}, 6$ June 1998, Atwood 23785 (BRY, MO, NY); $12 \mathrm{~km}$ NW of Murphy along Idaho Highway 78, T1S, R2W, Sec. 28, 785 m, 25 June 1991, DeBolt 1518 (NY); clay hills along Idaho Highway 51, $1.9 \mathrm{rd} \mathrm{mi} \mathrm{S}$ of Shoofly Road \& $8.2 \mathrm{rd} \mathrm{mi} \mathrm{S}$ of Idaho Highway 78, 9 air mi SSW of Bruneau, on

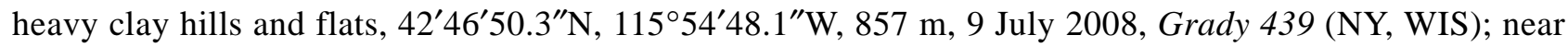
ORV trail S of Idaho Highway 78, $6.8 \mathrm{rd} \mathrm{mi} \mathrm{NW}$ of Murphy, on white silty tuffaceous badlands, $43^{\circ} 18^{\prime} 07.7^{\prime \prime} \mathrm{N}, 116^{\circ} 34^{\prime} 49.0^{\prime \prime} \mathrm{W}, 707 \mathrm{~m}, 9$ July 2008, Grady 443 (NY, WIS); $10 \mathrm{mi}$ S of Bruneau, 29 May 1946, Maguire \& Holmgren 26236 (BRY, CAS, DS, NY, UTC); Hart Creek Canyon W of Oreana, $43^{\circ} 01^{\prime} 00^{\prime \prime} \mathrm{N}$, $116^{\circ} 29^{\prime} 00 \mathrm{~W}, 3200 \mathrm{ft}$ elev., 8 August 1978, Rosentreter 268 (NY); Sugar Valley Badlands W of Bruneau, $42^{\circ} 48^{\prime} \mathrm{N}$, 11547’W, $2600 \mathrm{ft}$ elev., 3 June 1983, Rosentreter 3133 (NY); Little Jack Creek, T7S, R4E, Sec. 19, 3000 ft elev., 16 June 1982, Smithman et al. LS-0844 (NY). Twin Falls Co.: Along Yahoo Creek ca. 8 air mi S of Hagerman near Thousand Springs, 42 $45^{\prime} 00^{\prime \prime} \mathrm{N}, 114^{\circ} 55^{\prime} 00^{\prime \prime} \mathrm{W} 3200 \mathrm{ft}$ elev., 14 May 1980, Grimes et al. 1562 (NY); $10 \mathrm{mi}$ N of Twin Falls, 30 May 1946, Maguire \& Holmgren 26239 (BRY, CAS, DS, MO, NY, TEX, UC, UTC). Oregon: Baker Co.: $1.5 \mathrm{mi}$ from Durkee along Burnt River Road, 24 July 1976, Ertter et al. 2019 (BSU, NY); foothills of Iron Mountain along Burnt River Canyon Road just N of I-84, ca. 1 air mi NW of Durkee, on steep tan-white powdery-limy hillsides, $44^{\circ} 36^{\prime} 04.2^{\prime \prime} \mathrm{N}, 117^{\circ} 28^{\prime} 25.4^{\prime \prime} \mathrm{W}, 829 \mathrm{~m}, 9$ July 2009 , Grady 535 (NY, WIS); Huntington, 25 June 1930, M.E. Jones 25236 (CAS). Malheur Co.: 3-4 mi N of Harper, 3000 ft elev., 14 June 1955, Cronquist 7831 (CAN, CAS, DS, GH, ILL, KANS, MICH, MIN, MONTU, NY, RM, RSA, TEX, UC, UTC); $6.7 \mathrm{mi} \mathrm{N}$ of Harper along the Harper-Westfall Road, 19 May 1978, Grimes \& Packard 1132 (CIC, NY, UTC); chalky cliffs and hills along Harper/Westphal Rd, 7.1 rd mi N of U.S. Highway 20, 43 $55^{\prime} 51.4^{\prime \prime} \mathrm{N}, 117^{\circ} 39^{\prime} 52.4^{\prime \prime} \mathrm{W}, 846$ m, 4 July 2009, Grady \& Flores 523 (NY, WIS); 
McCarty Ridge E of Jamison, on bare white eroding hillside, $44^{\circ} 14^{\prime} 00^{\prime \prime} \mathrm{N}, 117^{\circ} 23^{\prime} 00^{\prime \prime} \mathrm{W}, 3 \mathrm{June} 1978$,

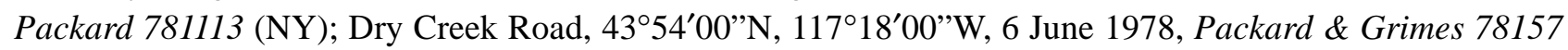
(BRY, CIC, NY, UTC); 11 mi SW of Vale, 19 June 1942, M.E. Peck 21297 (CAS, UC, WILLU); 7.2 mi N of U.S. Highway 20 N of Harper, 2850 ft elev., 17 June 1971, Reveal 2390 (BRY, CAS, GH, NY, OKL, RENO, RM, RSA, SD, UC, US, UTC).

Eriogonum crosbyae Reveal var. mystrium (Reveal) Grady \& Reveal, comb. nov., based on E. prociduum Reveal var. mystrium Reveal (2004b: 142). TYPE:-U.S.A. Oregon: Harney County: Little Cottonwood Creek, Pueblo Mountains., 14 mi N of Denio, T39N, R35E, Sec. 31, 4500-5000 ft elev. 14 June 1959, A. Cronquist 8439 (holotype NY, isotypes GH, MICH, OSC, RSA, TEX, UTC, WS, WTU).

Eriogonum crosbyae var. mystrium is now considered to be more closely allied to $E$. crosbyae, rather than $E$. prociduum, as previously treated (Reveal 2004b). The Pueblo Mountains wild buckwheat, a low, matted perennial, can be found in isolated populations across the north-central Great Basin. Most populations occur in extreme southeastern Oregon (Malheur \& Harney Counties), however additional collections have been made in the Santa Rosa Range, Humboldt Co., Nevada and remote areas of Owyhee Co., Idaho. This variety can be found growing at elevations from $1500 \mathrm{~m}$ to $2440 \mathrm{~m}$. It flowers from May to July depending on the elevation at which the plants grow. Eriogonum crosbyae var. mystrium does not seem to have a specific substrate preference, although it tends to be associated with more coarse-grained (sandy-gravelly) soils than its counterpart, E. crosbyae var. crosbyae.

Molecular data indicate that this variety is closely allied to $E$. crosbyae, hence the new combination proposed here. The Pueblo Mountains wild buckwheat also shares a suite of characters with E. crosbyae. Both varieties share similar compact growth forms and have membranous, campanulate involucres with floccose teeth. The pubescence of the flowering stems differs between these two varieties. The flowering stems of $E$. crosbyae var. mystrium are glabrous, whereas those of E. crosbyae var. crosbyae are floccose to tomentose.

Eriogonum prociduum occurs in the same general region of the Great Basin, although it and E. crosbyae var. mystrium never co-occur. These two taxa share similar growth forms, however, E. crosbyae var. mystrium exhibits more robust features (larger leaves and inflorescences). It is the size and appearance of the flowering stems that best differentiate these taxa. Eriogonum crosbyae var. mystrium has longer and thicker flowering stems, $0.6-1.1(-1.2) \mathrm{dm} \times>1 \mathrm{~mm}$, which are generally green in color. The flowering stems of E. prociduum have shorter and narrower flowering stems, these being $0.2-0.6(-0.7) \mathrm{dm} \times<1 \mathrm{~mm}$, and reddish in color.

Additional specimens examined:-U.S.A. Idaho: Owyhee Co.: near summit of South Mountain near abandoned BLM lookout tower, crest of windswept cobbley-gravelly ridge, soil derived from light-colored volcanic parent material, 42 $44^{\prime} 22.1^{\prime \prime} \mathrm{N}, 116^{\circ} 54^{\prime} 46.0^{\prime \prime} \mathrm{W}$, T8S, R5W, Sec. 10, $2371 \mathrm{~m}$ elev., 9 July 2008, Grady 442 (NY, WIS), ditto, 28 June 2005, Mansfield 5268 (CIC, NY); ditto, 13 August 1995, Moseley 2901 (NY); ditto, 2 June 1995, Reveal 7445 (MARY); ditto, 4 July 1992, Smithman \& Smithman LS-2554 (CIC, NY). Nevada: Humboldt Co.: Santa Rosa Range, SE side of Auto Hill, NW of Buckskin Mountain, T46N, R39E, Sec. 33, 6500 ft elev., 29 May 1987, Tiehm 11128 (NY); Santa Rosa Range, Auto Hill, 0.25 rd mi NNW

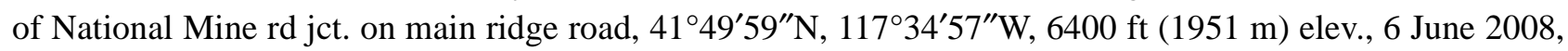
Tiehm \& Nachlinger 15589 (NY); Oregon: Harney Co.: Wild Horse Creek Canyon, E side of Steens Mountains, 22 May 1929, Applegate 5644 (DS); Little Cottonwood Creek, Pueblo Mountains, 1.5 mi past the Trout Creek/Fields-Denio Road, T40S, R34E, secs. 9/10, $6000 \mathrm{ft}$ elev., 10 June 1981, Grimes 2086 (BRY, CAS, MARY, NY, OSC, UTC); Machine Meadow-Roschense Place, head of Willow Creek, Pueblo Mountain, on barren gravel, T39S, R34E, Sec. 27, 6000 ft elev., 22 July 1980, Wright 1407 (MARY, OSC); ditto, 26 June 1980, Wright \& Franklin 1356 (MARY, OSC); ca $1 \mathrm{mi}$ E of McLean Hunting Cabin along road to Ten Cent Meadow, Pueblo Mountains, on bare gravel, T40S, R34E, Sec. 2, 22 July 1980, Wright 1408 (MARY, OSC); ridgetop above Denio Basin, Pueblo Mountains, on gravel, T41S, R34E, Sec. 10, 7000 ft elev., 23 July 1980, 
Wright 1411 (MARY); ridgetop above Denio Basin, Pueblo Mountains, on gravelly basaltic scree, T41S, R34E, Sec. 15, 6900 ft elev., 23 July 1980, Wright 1410 (MARY); ditto, 6800 ft elev., 23 July 1980, Wright 1413 (MARY); ditto, 11 June 1980, Wright \& Price 1321 (MARY, OSC). Malheur Co.: Oregon Canyon Mountains, along Disaster Peak Road 18.4 rd mi W of McDermitt, just W of Cottonwood/Mine Creek ca. 1 air mi SSW of Opalite Mine, gravelly calcareous substrate, $42^{\circ} 01^{\prime} 16^{\prime \prime} \mathrm{N}, 118^{\circ} 01^{\prime} 54.2^{\prime \prime} \mathrm{W}, 1523 \mathrm{~m}$ elev., 5 July 2009, Grady \& Flores 526 (WIS); Oregon Canyon Mountains, Brett (Opalite) Mine, $2.5 \mathrm{rd}$ mi N of Disaster Peak Road, 22.8 air mi W of McDermitt, growing mostly on steep hill of red, gravelly-sandy mine tailings, $42^{\circ} 03^{\prime} 00.3^{\prime \prime} \mathrm{N}, 118^{\circ} 02^{\prime} 13.7^{\prime \prime} \mathrm{W}, 1591 \mathrm{~m}$ elev., 5 July 2009, Grady \& Flores 528 (WIS).

\section{Eriogonum domitum Grady \& Reveal, sp. nov.}

A Eriogono manco foliis ellipticis ad orbiculatis (nec oblanceolatis ad spatulatis) et involucris rigidis (nec membranaceis) differt.

Type:-U.S.A.: Utah: Millard County, House Range, NE slope of Notch Peak ca. $100 \mathrm{~m}$ below summit, exposed limestone cliff edges in thin, silty, limy soil, associated with Cercocarpus and Ephedra, $39^{\circ} 08^{\prime} 35.6^{\prime \prime} \mathrm{N}, 113^{\circ} 24^{\prime} 25.7^{\prime \prime} \mathrm{W}, \mathrm{T} 19 \mathrm{~S}, \mathrm{R} 14 \mathrm{~W}$, Sec. 22, $2832 \mathrm{~m}$ (9293ft) elev., 6 July 2010, Grady \& Heyduk 638 (holotype NY, isotypes BH, BRY, US, UTC, WIS, and elsewhere).

Plants low, pulvinate perennial herbs forming mats to $1 \mathrm{dm}$ across from underground branching caudex; leaves basal, semi-erect, fasciculate in terminal tufts, the petioles (1-)3-6 mm long, tomentose, the leaf-blades elliptic to orbicular, (5-)6-12 $\times(3-) 5-9 \mathrm{~mm}$, densely grayish tomentose abaxially, less so and greenish adaxially, the apex and leaf base rounded, the margins plane; flowering stems scape-like, erect to semi-erect, 2-5(-5.5) cm, tomentose, grayish; inflorescences capitate, (0.8-)1-1.5 cm wide; bracts 5-6, scale-like, 1-2.5 $\mathrm{mm}$ long, narrowly triangular; peduncles lacking; involucres congested, 4-7, campanulate, rigid, (1.5-)2-3 $\times$ 1.5-2(-2.5) $\mathrm{mm}$, tomentose, the teeth 5, 0.6-1.0(-1.2) $\mathrm{mm}$ long; flowers $2.5-3.5 \mathrm{~mm}$ long on pedicels $2-3$ $\mathrm{mm}$ long, the perianth white to pink to rose or magenta with red midvein, glabrous, the hypanthium 1/3-1/2 length of perianth, the tepals monomorphic; stamens exserted, 2-3 mm long, the filaments usually sparsely pilose basally; achenes trigonous, light brown, 2-2.5(-3) $\mathrm{mm}$ long, glabrous except for a minutely papillate beak.

Distribution and habitat:-Like many other capitate members of Eriogonum subg. Eucycla, E. domitum is a narrowly distributed edaphic endemic species. As such, E. domitum is known only from high limestone ridges in the House Range of west-central Utah. The House Range wild buckwheat occurs in a fairly narrow elevation band of 2760-2900 m, higher than the pinyon-juniper woodland. Individuals are found most often in a thin limy soil that accumulates in fractures of Notch Peak limestone. This species has only been observed by the authors flowering in July, but presumably produces flowers in June, continuing into August.

Etymology:- The specific epithet, domitum, means "of the house", referring to the House Range, to which this species is endemic.

Observations:-Morphologically, Eriogonum domitum resembles E. mancum, the former previously considered to be a relict population of that more northerly species (Reveal 2005). Ongoing molecular studies indicate that E. domitum has a distinct evolutionary history from that of E. mancum (Grady \& Sytsma, unpublished data). In the field, these species can be distinguished by the leaf blade shape and the appearance of the involucres. The leaves of $E$. domitum are elliptic to orbicular on a well-defined petiole, while those of E. mancum are oblanceolate to spatulate with the blade grading into the petiole. The involucres of $E$. domitum are distinctly rigid and turbinate in shape, as compared to the membranous, open-campanulate involucres of E. mancum. Geographically, these two species are separated by nearly $500 \mathrm{~km}$.

Eriogonum holmgrenii Reveal (1965: 184), another capitate member of subg. Eucycla, also occurs on high-elevation calcareous substrates in the eastern portion of the Great Basin Desert. Although E. holmgrenii and E. domitum are separated by only ca. $80 \mathrm{~km}$, much of the intervening area is low-elevation basin, with a 
drastically different moisture regime and geology than either species currently occupies. Though similar ecologically, these two species are easy to distinguish based on pubescence. Glandular trichomes cover the flowering stems, leaves and the perianth of E. holmgrenii. All trichomes on the vegetative and floral structures of $E$. domitum are simple and non-glandular.

The species will be illustrated in a forth-coming volume of the Intermountain Flora.

Additional specimens examined (paratypes):-U.S.A. Utah: Millard Co.: House Range, summit of Pine Peak ca. 1.5 air mi N of Notch Peak, limestone outcrops and gravel, gray silty-limy soil, 39 $09^{\prime} 59.3^{\prime \prime} \mathrm{N}$, $113^{\circ} 24^{\prime} 33.3^{\prime \prime} \mathrm{W}, \mathrm{T} 19 \mathrm{~S}, \mathrm{R} 14 \mathrm{~W}$, Sec. 10, 2820 m (9250 ft) elev., 22 July 2009, Grady 575 (NY, WIS); ca. halfway between Pine Peak and Notch Peak, steep ridgeline of limestone gravel, gray silty-limy soil, $39^{\circ} 09^{\prime} 23.2^{\prime \prime} \mathrm{N}, 113^{\circ} 24^{\prime} 38.5^{\prime \prime} \mathrm{W}, \mathrm{T} 19 \mathrm{~S}, \mathrm{R} 14 \mathrm{~W}$, Sec. 15, $2830 \mathrm{~m}$ (9285 ft) elev., 22 July 2009, Grady 578 (WIS); House Range, limestone ridge ca. $1 / 2$ mi ESE of Notch Peak, silty, limy soil and limestone gravel and cobbles, $39^{\circ} 08^{\prime} 29.2^{\prime \prime} \mathrm{N}, 113^{\circ} 24^{\prime} 06.1^{\prime \prime} \mathrm{W}, \mathrm{T} 19 \mathrm{~S}, \mathrm{R} 14 \mathrm{~W}$, Sec. 22, $2765 \mathrm{~m}$ (9072 ft) elev., 6 July 2010, Grady \& Heyduk 636 (WIS).

\section{Acknowledgements}

The first author thanks the American Philosophical Society, American Society of Plant Taxonomists, the University of Wisconsin Botany Department, and the Native Plant Societies of Nevada, Oregon, and Utah for providing funding to support collecting efforts for these, and other species of Eriogonum. He also expresses gratitude to the following herbaria for granting access to their collections: BH, BRY, NY, RENO, UTC, WIS. Over his much longer association with Eriogonum, the second author has examined material at far more herbaria as may be noted in the specimen examined sections. Finally we thank Noel H. Holmgren (NY), Hans-Joachim Esser, and an anonymous reviewer for their comments and suggestions.

\section{References}

Kuntze, O. (1903) Eriogonum. In: T. von Post \& O. Kuntze, Lexicon generum phanerogamarum. Published by the authors, Stuttgart.

Michaux, A. (1803) Flora boreali-americana. 2 vols. C. Crapelet, Paris.

Nuttall, T. (1848) Descriptions of plants collected by Mr. William Gambel in the Rocky Mountains and Upper California. Proceedings of the Academy of Natural Sciences of Philadelphia 4: 7-26.

Peck, M.E. (1945) Some interesting plants of Malheur County, Oregon. Leaflets of Western Botany 4: 177-196.

Reveal, J.L. (1965) A new alpine Eriogonum from Nevada. Leaflets of Western Botany 10: 183-186.

Reveal, J.L. (1972) Two new species of Eriogonum (Polygonaceae) from California and adjacent states. Aliso 7: 415419.

Reveal J.L. (1981) Notes on endangered buckwheats (Eriogonum: Polygonaceae) with three newly described species from the western United States. Brittonia 33: 441-448.

Reveal, J.L. (1985) New Nevada entities and combinations in Eriogonum (Polygonaceae). Great Basin Naturalist 45: 276-280.

Reveal, J.L. (1989) New combinations and novelties in Eriogonum (Polygonaceae: Eriogonoideae). Phytologia 66: 251265.

Reveal, J.L. (2004a) Nomenclatural summary of Polygonaceae subfamily Eriogonoideae. Harvard Papers in Botany 9:143-230.

Reveal, J.L. (2004b) New entities in Eriogonum (Polygonaceae: Eriogonoideae). Phytologia 86: 121-159.

Reveal, J.L. (2005) Polygonaceae Jussieu subfam. Eriogonoideae Arnott. Flora of North America North of Mexico 5. Oxford University Press, New York, pp. 218-478.

Rydberg, P.A. (1917) Flora of the Rocky Mountains and adjacent plains. Hafner Publishing, New York, pp. 220-221.

Stokes, S.G. (1936) The genus Eriogonum. A preliminary study based on geographic distribution. J.H. Neblett Pressroom, San Francisco.

Watson, S. (1880) Botany Volume II. John Wilson and Son, University Press, Cambridge, Massachusetts. 